\title{
Multivariate analysis of potentially toxic elements in surface waters in Ethiopia
}

\author{
Minbale Aschale $^{1} \cdot$ Yilma Sileshi $^{2} \cdot$ Mary Kelly-Quinn $^{3} \cdot$ Dereje Hailu $^{2}$
}

Received: 4 March 2019 / Accepted: 13 April 2021 / Published online: 22 April 2021

(c) The Author(s) 2021

\begin{abstract}
The Akaki River and its tributaries, in the city of Addis Ababa, are polluted by potentially toxic elements (PTEs) (Sb, Zn, $\mathrm{Cd}, \mathrm{As}, \mathrm{Hg}, \mathrm{Cu}, \mathrm{Pb}, \mathrm{Fe}, \mathrm{V}, \mathrm{Ni}, \mathrm{Co}, \mathrm{Mn}, \mathrm{Cr}, \mathrm{B}, \mathrm{Sr}$ and $\mathrm{Ba}$ ) in varying degrees due to the significantly fast urban expansion and the industrial activities. The water samples collected from twenty-six different locations or sampling sites along the River and some of its tributaries were analyzed by ICP-MS to determine PTEs. The multivariate component analysis was used to evaluate the relationship and interdependency among the PTEs. The results showed that the mean concentrations for most of PTEs exceeded the recommended limits of drinking and irrigation water quality guidelines. A strong and positive relationship was observed among many of PTEs in the river water indicating common sources. The concentrations of many PTEs in the study area exceeded those previously reported and also varied with site or location, signifying localized contributions of the different contaminants associated with municipal, domestic, industrial, hospitals, garages and other activities. These findings of this study should help highlight and focus water quality management on key PTEs of concern and prioritize efforts to mitigate their release into surface waters in the city. Given the potential health implications of the PTEs mitigation measures should be sought as a matter of urgency by the relevant authorities in Ethiopia.
\end{abstract}

Keywords Pollution $\cdot$ Industrial activities $\cdot$ PTEs $\cdot$ Akaki River $\cdot$ Multivariate analysis

\section{Introduction}

Water pollution is a serious global environmental issue. Surface waters are the major recipient of contaminants from different point and non-point sources, for instance industrial activities, municipal, domestic, agricultural practices, urban runoff, leachate, mining of ore, and weathering (Zarazua et al. 2006; Gupta et al. 2009; Sekabira et al. 2010). A major concern about pollutants in aquatic ecosystems is the negative health effects that they could cause to living organisms (Munk and Faure 2004). The physico-chemical properties of water bodies are also influenced by a variety of factors including interaction with geology, topography,

Minbale Aschale

minable.aschale@techin.gov.et; minsinas@yahoo.com

1 Technology and Innovation Institute of Ethiopia, Addis Ababa, Ethiopia

2 School of Civil and Environmental Engineering, Addis Ababa University, Addis Ababa, Ethiopia

3 School of Biology and Environmental Sciences, University College Dublin, Dublin, Ireland and vegetation cover (Han and Liu 2004). Water pollutants can be broadly classified into a number of major categories, namely organic, inorganic, suspended solids and sediments, and PTEs such as heavy metals and radioactive materials (Botikin and Keller 1995). Of the various pollutants, PTE pollution of the aquatic environment has generated concern in recent years because of their toxicity to aquatic organisms at certain concentrations (Shao and Wen 2004; Lee et al. 2007).

Toxic and PTEs could be present in higher amounts than the background levels or concentrations, and thus pollute aquatic ecosystems and affect aquatic living organisms (Akan et al. 2013). They cause damage to the kidney, the nervous system, gastrointestinal, cancer, heart and even death due to their long half-life, non-biodegradable nature, and their accumulation in different parts of living organisms (Lohani et al. 2008; Marta and Raul 2008). The most common PTEs listed by the Environmental Protection Agency of the United States are chromium $(\mathrm{Cr})$, lead $(\mathrm{Pb})$, arsenic (As), cadmium $(\mathrm{Cd})$, mercury $(\mathrm{Hg})$, antimony $(\mathrm{Sb})$, nickel (Ni) and zinc $(\mathrm{Zn})$. The toxicity, reactivity and bioavailability of a number of PTEs such as As and $\mathrm{Cr}$ are based on 
chemical speciation of the element (Pandey and Madhuri 2014). Some of PTEs are essential for the metabolism of living organisms. PTEs such as cobalt (Co), chromium $(\mathrm{Cr})$, copper $(\mathrm{Cu})$, nickel $(\mathrm{Ni})$, manganese $(\mathrm{Mn})$, iron $(\mathrm{Fe})$ and zinc $(\mathrm{Zn})$ are required by organisms at low levels, but they can be harmful to their physiology at high concentrations. Non-essential elements including $\mathrm{As}, \mathrm{Pb}, \mathrm{Hg}$ and $\mathrm{Cd}$ are toxic to living organisms at any levels (Kar et al. 2008; Nair et al. 2010). When compared to other types of aquatic pollution, PTEs pollution is less visible, but its effects on living organisms can be intensive and very extensive. Furthermore, many PTEs have a tendency to stay in ecosystems and passthrough from one component to others (Edem et al. 2008).

In Addis Ababa, Ethiopia provision of wastewater infrastructure has not kept pace with rapid population and urbanization growth in the city. As a result, huge quantities of solid and liquid wastes are produced every day from a variety of point and non-point sources. Accordingly, commercial, new, as well as old industries, domestic and public utilities release untreated solid and liquid wastes into any receiving aquatic environment found nearby (Tamiru 2001; Daniel et al. 2007; Melaku et al. 2004). Consequently, such direct or indirect discharge of solid and liquid wastes into nearby water bodies has remarkably increased the levels of contaminants in the rivers, streams and shallow groundwater reservoirs (Tamiru et al. 2005). In addition to this, a considerable amount of wastes dumped on open ground enter into rivers and streams by surface runoff.

Surface water in Addis Ababa has become contaminated with various pollutants such as pesticides, toxic and potentially toxic trace heavy metals, detergents, oils, solvents, nitrates, chlorides, sulfates and phosphates (Itanna 1998; Melaku et al. 2004; Weldegebriel et al. 2012; Kebede et al. 2012). PTEs contamination levels in the sediments of the Akaki River and its main tributaries in Addis Ababa are attributed to principally large-scale and small-scale industrial activities, disposal of municipal and domestic wastes (Melaku et al. 2005; Aschale et al. 2016). Agricultural areas located in Kolfea-Keranyo, Akaki sub-cities and Nefasilk-Lafto use water for irrigation from the Akaki River and its tributaries which are heavily polluted from different sources (AAEPA 2008). Melaku et al. (2004) reported elevated concentrations of $\mathrm{Cr}, \mathrm{Cd}, \mathrm{Co}, \mathrm{Cu}, \mathrm{Ni}, \mathrm{Pb}, \mathrm{Zn}$ and $\mathrm{Mn}$ in the water of Akaki River and some of its tributaries due to mainly industrial activities, disposal of domestic and municipal wastes. Kebede et al. (2012) studied some freshwater bodies in Ethiopia and found that the concentrations of $\mathrm{Cr}, \mathrm{Mn}, \mathrm{Co}, \mathrm{Ni}$ and $\mathrm{Pb}$ were also generally elevated because of the disposal of industrial and domestic wastes. As a result, there is a risk to human health from the intake of PTEs through consumption of vegetables and drinking the river water. This paper presents new analysis on the data collected by Aschale et al. (2015) to identify relationships between the detected PTEs that can help identify the sources of the contaminants. To the best of the researcher's knowledge to date, there have been limited studies and knowledge pertaining to the sources, and correlations between levels of the various PTEs in the study area. Therefore, detailed information pertaining to the current concentrations of PTEs in the surface water and how to deal with these pollution problems in Ethiopia will be essential to inform monitoring exercises to address the pollution problems and establish environmental management systems.

\section{Materials and methods}

\section{Study area}

Representative samples of the water were collected from rivers in the city of Addis Ababa, Ethiopia (Fig. 1). Addis Ababa is the nation's capital, and the country's commercial, industrial, cultural, administrative and communications center. It is geographically located at $9^{\circ} \mathrm{N}$ and $38^{\circ} \mathrm{E}$ between 2200 and $2500 \mathrm{~m}$ above sea level. Geologically, Addis Ababa lies on volcanic rocks varying in composition and structure from rhyolitic to basaltic types. The major stratigraphic units are composed of rhyolitic, trachytic, basaltic and trachy-basaltic lava flows and welded tuffs found in different localities and ages. Despite its proximity to the equator, Addis Ababa enjoys a mild, Afro-Alpine and warm temperate climate. The annual average temperature ranges from $10{ }^{\circ} \mathrm{C}$ in the wet season to $25^{\circ} \mathrm{C}$ in the dry season. Both April and May are the driest months in Ethiopia. Annual rainfall in Addis Ababa is generally between 800 and $1000 \mathrm{~mm}$. The main rainy season takes place between midJune and mid-September, which is responsible for about $70 \%$ of the yearly average rainfall of $1400 \mathrm{~mm}$. It is characterized by heavy rainfall of short duration. During the rainy season, both nights and days are cool while in the dry season the nights are cool and days are pleasantly warm.

The aquifers of the northern and central part of Addis Ababa city and in the mountain area are largely due to weathered and fractured volcanic rock with minor sediments deposited between different series of lava flows. The aquifers at the southern part of the city (Akaki well field) are mainly young volcanic rocks of lava flow and tectonic fractures. In general, the aquifers are complex and highly variable. About $65 \%$ of the medium and large-scale industries of Ethiopia are found in Addis Ababa (Gebre and Rooijen 2009). Some of the industrial activities in the city are cement, pharmaceuticals, beverage and food production, textile, tobacco, chemical products, plastics and leather (Fig. 1). Currently, it has a population of more than 5 million and a land area of $540 \mathrm{sq} \mathrm{km}$. The main land-use features in the city include industrial areas, residential areas, meadows, open markets, 


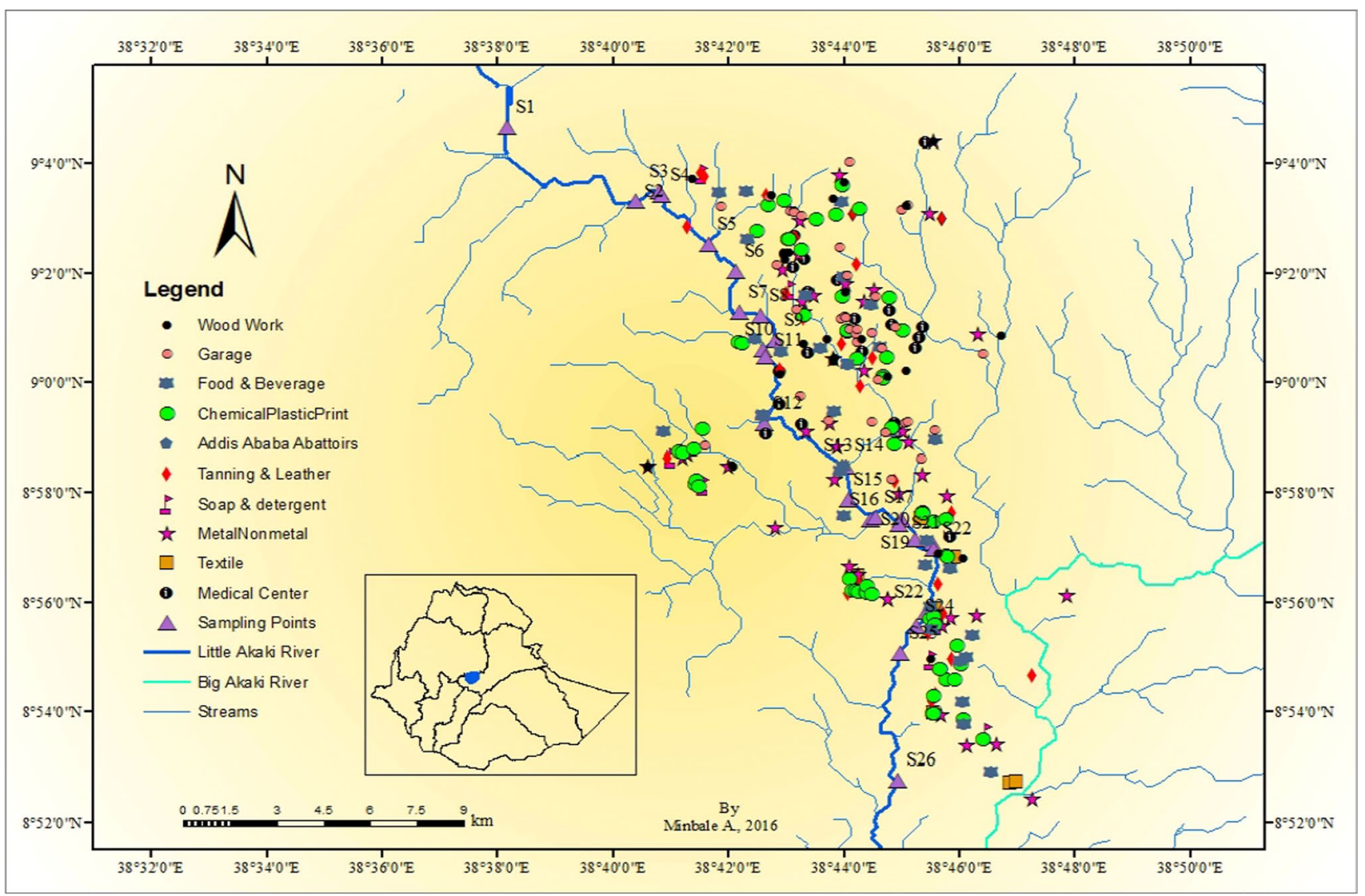

Fig. 1 Location of sampling sites, various industries and other potential sources of PTEs

quarries, small-scale agricultural fields and forest. In the city, more than 160 ha of agricultural land are annually used to grow vegetables.

There are two main rivers that flowing through the city of Addis Ababa. The first one is the Little Akaki River (locally known as Tinishu Akaki River) which flows through the western part of the city. It has a catchment area of about $540 \mathrm{~km}^{2}$. The second one is the Big Akaki River (locally, Tiliku Akaki River) which flows through the eastern part of the city, and it has a catchment area of about $900 \mathrm{~km}^{2}$ (Fig. 1). The upper courses of these two rivers begin from the northern mountains catchment area. When these rivers cross through industrial, densely populated residential and commercial areas of the city, they are exposed to a variety of sources of pollution.

The Little Akaki River starts near Gefersa and crosses through the central city of Addis Ababa. Most streams that flow from northwestern parts of the city meet at the Gullele area and flows downwards to the main densely settled areas of the city in which many residents and commercial centers are found. Most of the industries such as tanneries, textiles, woodworks, pharmaceuticals, food and beverages, rubber and plastic, and metal products whose wastewaters are discharged into the nearby environment especially to water are most often untreated (Fig. 1). The Little Akaki River catchments include Gullele, Merkato, Ledeta, Mekanissa, Kolfea, Lafto and part of Kaliti areas. Despite its black color, offensive odor and toxicity, the river is still used as a source of livestock watering, washing, cooking, and irrigation to produce a range of vegetables including swiss chard, lettuce, potato, cabbage, carrot and onions.

\section{Sample collection and analysis}

A total of 26 sampling sites (S1-S26) were selected based on the possible sources of PTEs, agricultural activities, population density and other possible sources of pollutants. All the coordinates of sampling locations were recorded using a GPS (Global Positioning System) instrument (Garmintm Nuvi 200). The location of the sampling sites and details of each is given in Fig. 1 and Table 1, respectively. The sites included diversion points for irrigation and some of the tributaries that enter the Little Akaki River. At each site, $500 \mathrm{~mL}$ of surface water sample was collected by lowering pre-cleaned polyethylene bottles into the upper surface $(30-50 \mathrm{~cm})$ of the river. Before taking the final water samples, the bottles were rinsed three times with the river water 
Table 1 Description of sampling sites in the study area in Addis Ababa

\begin{tabular}{|c|c|c|c|c|}
\hline Site & Elevation $(\mathrm{m})$ & Location & & Description \\
\hline $\mathrm{S} 1$ & 2597 & $09^{\circ} 4.643^{\prime} \mathrm{N}$ & $038^{\circ} 38.161^{\prime} \mathrm{E}$ & Gefersa River before entering water treatment plant \\
\hline $\mathrm{S} 2$ & 2516 & $09^{\circ} 3.314^{\prime} \mathrm{N}$ & $038^{\circ} 40.393^{\prime} \mathrm{E}$ & Gefersa River after water treatment plant \\
\hline S3 & 2507 & $09^{\circ} 3.497^{\prime} \mathrm{N}$ & $038^{\circ} 40.802^{\prime} \mathrm{E}$ & Burayu River \\
\hline $\mathrm{S} 4$ & 2502 & $09^{\circ} 3.430^{\prime} \mathrm{N}$ & $038^{\circ} 40.842^{\prime} \mathrm{E}$ & LAR after mixing with Gefersa and Burayu River \\
\hline S5 & 2426 & $09^{\circ} 2.525^{\prime} \mathrm{N}$ & $038^{\circ} 41.651^{\prime} \mathrm{E}$ & LAR after mixing with Addis Ababa Tannery and glass factory \\
\hline S6 & 2401 & $09^{\circ} 2.035^{\prime} \mathrm{N}$ & $038^{\circ} 42.118^{\prime} \mathrm{E}$ & LAR at the bridge of Kolfea \\
\hline S7 & 2351 & $09^{\circ} 01.293^{\prime} \mathrm{N}$ & $38^{\circ} 42.183^{\prime} \mathrm{E}$ & LAR after mixing with Gerbeja River \\
\hline S8 & 2352 & $09^{\circ} 01.232^{\prime} \mathrm{N}$ & $038^{\circ} 42.540^{\prime} \mathrm{E}$ & Worenchiti River \\
\hline S9 & 2348 & $09^{\circ} 00.780^{\prime} \mathrm{N}$ & $038^{\circ} 42.811^{\prime} \mathrm{E}$ & LAR after mixing with Worenchiti River \\
\hline $\mathrm{S} 10$ & 2325 & $09^{\circ} 00.597^{\prime} \mathrm{N}$ & $038^{\circ} 42.587^{\prime} \mathrm{E}$ & Melkaqurani River \\
\hline $\mathrm{S} 11$ & 2322 & $09^{\circ} 00.475^{\prime} \mathrm{N}$ & $038^{\circ} 42.644^{\prime} \mathrm{E}$ & LAR after mixing with Melkaqurani River \\
\hline $\mathrm{S} 12$ & 2254 & $08^{\circ} 59.252^{\prime} \mathrm{N}$ & $038^{\circ} 42.608^{\prime} \mathrm{E}$ & LAR at Zenebe work: receives Alert hospital and domestic \\
\hline $\mathrm{S} 13$ & 2224 & $08^{\circ} 58.478^{\prime} \mathrm{N}$ & $038^{\circ} 43.969^{\prime} \mathrm{E}$ & LAR at Mekanisa after mixing with National Alcohol Wastes \\
\hline $\mathrm{S} 14$ & 2215 & $08^{\circ} 58.487^{\prime} \mathrm{N}$ & $038^{\circ} 44.025^{\prime} \mathrm{E}$ & Kera River: It receives Abattoir and slaughter house wastes \\
\hline S15 & 2212 & $08^{\circ} 57.890^{\prime} \mathrm{N}$ & $038^{\circ} 44.064^{\prime} \mathrm{E}$ & LAR at Gofa after mixing with Kera River \\
\hline S16 & 2215 & $8^{\circ} 57.511^{\prime} \mathrm{N}$ & $038^{\circ} 44.458^{\prime} \mathrm{E}$ & Lafto River \\
\hline S17 & 2214 & $8^{\circ} 57.555^{\prime} \mathrm{N}$ & $038^{\circ} 44.537^{\prime} \mathrm{E}$ & LAR after mixing with Lafto River \\
\hline $\mathrm{S} 18$ & 2206 & $08^{\circ} 57.522^{\prime} \mathrm{N}$ & $038^{\circ} 44.978^{\prime} \mathrm{E}$ & Jaja stream \\
\hline S19 & 2203 & $08^{\circ} 57.445^{\prime} \mathrm{N}$ & $038^{\circ} 44.953^{\prime} \mathrm{E}$ & LAR after mixing with Jaja River \\
\hline $\mathrm{S} 20$ & 2213 & $08^{\circ} 57.152^{\prime} \mathrm{N}$ & $038^{\circ} 45.230^{\prime} \mathrm{E}$ & LAR at Biheretsige \\
\hline $\mathrm{S} 21$ & 2197 & $08^{\circ} 57.090^{\prime} \mathrm{N}$ & $038^{\circ} 45.527^{\prime} \mathrm{E}$ & Kaba River: receives industrial, domestic and public wastes \\
\hline $\mathrm{S} 22$ & 2202 & $08^{\circ} 56.988^{\prime} \mathrm{N}$ & $038^{\circ} 45.541^{\prime} \mathrm{E}$ & LAR after mixing with Kaba River \\
\hline $\mathrm{S} 23$ & 2145 & $08^{\circ} 55.836^{\prime} \mathrm{N}$ & $038^{\circ} 45.424^{\prime} \mathrm{E}$ & LAR before the Kaliti bridge and after mixing with Batu Tannery \\
\hline $\mathrm{S} 24$ & 2147 & $08^{\circ} 55.571^{\prime} \mathrm{N}$ & $38^{\circ} 45.237^{\prime} \mathrm{E}$ & LAR after mixing the effluent of leather and DESCO factory \\
\hline S25 & 2126 & $08^{\circ} 55.073^{\prime} \mathrm{N}$ & $038^{\circ} 44.976^{\prime} \mathrm{E}$ & LAR at Kaliti after mixing with Wastewater Treatment Plant \\
\hline S26 & 2062 & $08^{\circ} 52.771^{\prime} \mathrm{N}$ & $38^{\circ} 44.932^{\prime} \mathrm{E}$ & LAR before entering to Aba Samuel reservoir: Yetu Kebele \\
\hline
\end{tabular}

to be collected. Sampling took place between February and June 2014.

The water samples were brought to the laboratory and filtered using Whatman No. 42 filter paper and preserved with $1 \mathrm{~mL}$ of $0.5 \% \mathrm{HNO}_{3}$ in $500 \mathrm{~mL}$ polyethylene bottles. At all stages of sampling and analysis, care was taken to avoid contamination of samples and to minimize loss of analyte by adsorption onto the walls of the containers. The filtered samples were stored in a refrigerator at $4{ }^{\circ} \mathrm{C}$ to minimize volatilization and biodegradation during sampling and analysis periods. The resulting mixture was analyzed by inductively coupled plasma mass spectrometry (ICP-MS) for cadmium (Cd), arsenic (As), nickel (Ni), chromium (Cr), strontium $(\mathrm{Sr})$, zinc $(\mathrm{Zn})$, manganese $(\mathrm{Mn})$, copper $(\mathrm{Cu})$, barium $(\mathrm{Ba})$, iron $(\mathrm{Fe})$, antimony $(\mathrm{Sb})$, mercury $(\mathrm{Hg})$, vanadium $(\mathrm{V})$, cobalt $(\mathrm{Co})$ and boron $(\mathrm{B})$ contents in the laboratory of Irish Environmental Protection Agency (IEPA) in Dublin, Ireland. When the element of interest has more than one isotope, careful selection of the isotopes of the given element is critical. The masses of at least two were monitored and the isotope with less interference and higher abundance was selected. And thus, ${ }^{10} \mathrm{~B},{ }^{51} \mathrm{~V},{ }^{52} \mathrm{Cr},{ }^{54} \mathrm{Fe},{ }^{55} \mathrm{Mn},{ }^{58} \mathrm{Ni},{ }^{59} \mathrm{Co}$,
${ }^{65} \mathrm{Cu},{ }^{66} \mathrm{Zn},{ }^{75} \mathrm{As},{ }^{87} \mathrm{Sr},{ }^{114} \mathrm{Cd},{ }^{121} \mathrm{Sb},{ }^{137} \mathrm{Ba},{ }^{202} \mathrm{Hg}$ and ${ }^{208} \mathrm{~Pb}$ isotopes were used for this analysis.

\section{Quality control and assurance}

All chemicals used in this work were of analytical grade. All of the determinations were duplicated to ensure the representativeness of the results. Each collected water sample was examined in triplicate and sample duplicates were performed for every batch of 10 samples. Calibrations were frequently generated to assess the performances of the instrumental techniques and were acceptable for all analyzed PTEs with a correlation coefficient $(r)>0.99$. To examine the precision and accuracy of the elemental concentration in river water samples, quality control multi-element standard solutions (ICP-MS Quality Standard, USA) were used. The results of the analysis were reliable when a duplicate sample error was below $5 \%$ and the precision for the replicate samples of the water was below $10 \%$. The limit of detection was found to be in the range of $0.01-3.00 \mu \mathrm{g} / \mathrm{L}$, whereas LOQ ranged between 0.02 and $10 \mu \mathrm{g} / \mathrm{L}$. All the samples of the matrix, wash solutions, standards and quality control were 
prepared using $\mathrm{HNO}_{3}$. All sample containers were kept in sealed polyethylene until collection. Supra pure grade $\mathrm{HNO}_{3}$ was employed to acidify the collected water samples.

\section{Statistical analysis}

ANOVA was used to assess significant differences at different sampling locations or sites. Statistical significance was detected when the $p$ value was equal to or less than 0.05 . The homogeneity of variance and normal distribution of PTEs in sample stations were tested by using Levene statistic and the Shapiro-Wilk methods, respectively. A logarithmic transformation was performed on the dataset to improve normality. Multivariate analysis of PTEs dataset was carried out by using Pearson's correlation coefficient analysis, cluster and principal component analysis. A Pearson correlation coefficient matrix was developed between the investigated elements to assess the strength of inter-metallic relationships and to support the results obtained by multivariate analysis. PCA using varimax normalized rotation was conducted for common source identification. The appropriateness of the dataset for PCA was assessed using Bartlett's Sphericity and Kaiser-Meyer-Olkin (KMO) tests. In PCA analysis, the position of samples in the new coordinate system is represented by the score matrix, while the loadings matrix gives the importance (weight) of original variables on the PCs. In this study, the agglomerative hierarchical cluster analysis according to Ward's method with Euclidian distance as the criterion was applied to detect multivariate similarities in the pollution levels of the Akaki River and its main streams or tributaries.

\section{Results and discussion}

\section{Analysis of PTEs in water samples}

Concentrations of PTEs in the samples of water along with the relevant threshold values are shown in Table 2. The one-way ANOVA showed that the values of PTEs among sampling sites varied significantly depending on sampling locations $(p<0.05)$. The variability from upstream to downstream of the river is related to the discharge of wastes from municipal and domestic activities, industrial, geologic deposits and from agricultural wastes which contribute significantly to the PTEs load of the river. The elevated levels of PTEs in the river and its tributaries originate mainly from industrial activities (Itanna 1998; Tamiru 2001; Melaku et al. 2004; Kebede et al. 2012). The PTEs concentrations were lower in the downstream sites of the study area $(p<0.05)$, this could be due to the river and its tributaries being diverted extensively for irrigation purposes and inputs from some of the tributaries or main streams which are relatively unpolluted and thus play a dilution role (Table 2). Irrigation of vegetables is carried out by direct flooding the crop roots after diverting the river and its main tributaries and/or motor pumping by gravity taking the advantage of the local topography. Similar trends have been previously observed in the water samples from the Akaki River and its tributaries (Melaku et al. 2004).

The concentrations of $\mathrm{Cr}$ in the water samples ranged from 1.25 to $485.01 \mu \mathrm{g} / \mathrm{L}$ with the mean value of $67.04 \mu \mathrm{g} / \mathrm{L}$. Cr concentrations at Sites S5, S6, S7, S9, S11, S12, S23, S24 and S25 did not fulfill drinking water quality criteria set by the WHO (2011), EU (1998) and Ethiopian Standards (2001) (Table 2). The water samples at Sites S5, S6, S7 and S24 were also not appropriate for irrigation uses (FOA, 1994). If the SI 272 of 2009 annual average threshold value for Cr was applied all, but at Sites S2, S3, S4, S10, S14, S18 and $\mathrm{S} 20$, would be considered impacted. The exceedances are related to the discharge from industrial activities such as Batu tannery, Wallia tannery, Addis Ababa tannery, and Kality leather factory. The concentrations of $\mathrm{Pb}$ in the study area varied from 1.15 to $11.35 \mu \mathrm{g} / \mathrm{L}$ with the mean value of $3.13 \mu \mathrm{g} / \mathrm{L}$ (Table 2). The acceptable limit of $\mathrm{Pb}$ in drinking water according to the WHO, EU and Ethiopian standards is $10 \mu \mathrm{g} / \mathrm{L}$. The values obtained in all the analyzed samples were below this limit except at Site S8. The concentrations of $\mathrm{Pb}$ at Sites S5, S8 and S9 exceeded the annual average threshold value of $7.2 \mu \mathrm{g} / \mathrm{L}$ for surface water set in SI 272 of 2009. However, the $\mathrm{Pb}$ levels were less than the international guideline value for irrigation water of $5000 \mu \mathrm{g} / \mathrm{L}$ (FAO 1994).

The recommended guideline values of $\mathrm{Hg}$ are $0.1,0.6$ and $1 \mu \mathrm{g} / \mathrm{L}$ for drinking water as given by the EU, WHO and Ethiopian standards, respectively. $\mathrm{Hg}$ concentrations in all the river water samples were below the detection limit and thus not of concern. The concentrations of $\mathrm{Cu}$ in the water samples ranged from 2.1 to $11.55 \mu \mathrm{g} / \mathrm{L}$ with the mean value of $5.61 \mu \mathrm{g} / \mathrm{L}$. The recommended limit of $\mathrm{Cu}$ in drinking water is $2000 \mu \mathrm{g} / \mathrm{L}$ as given by the $\mathrm{EU}, \mathrm{WHO}$ and Ethiopian standards. As shown in Table 2, all the samples had lower $\mathrm{Cu}$ levels within the safe limit for drinking and irrigation water. However, the values of $\mathrm{Cu}$ at all sampling sites, except at Sites S4, S6, S7, S10, S13, S16, S17 and S18, exceeded the $5 \mu \mathrm{g} / \mathrm{L}$ annual average threshold in SI 272 of 2009 for surface water with hardness value less than or equal to $100 \mathrm{mg} / \mathrm{L} \mathrm{CaCO}_{3}$. High levels of $\mathrm{Cu}$ at the sites sampled may be due to discharges of industrial, municipal and domestic effluent.

The concentrations of Co were in the range of 0.5 to $8.85 \mu \mathrm{g} / \mathrm{L}$ with the mean value of $2.62 \mu \mathrm{g} / \mathrm{L}$. No guideline values for Co in drinking water are given by the WHO, EU and Ethiopian standards. This is probably because Co is not a health concern at concentrations normally observed in drinking water. Although the mean concentration of Co 


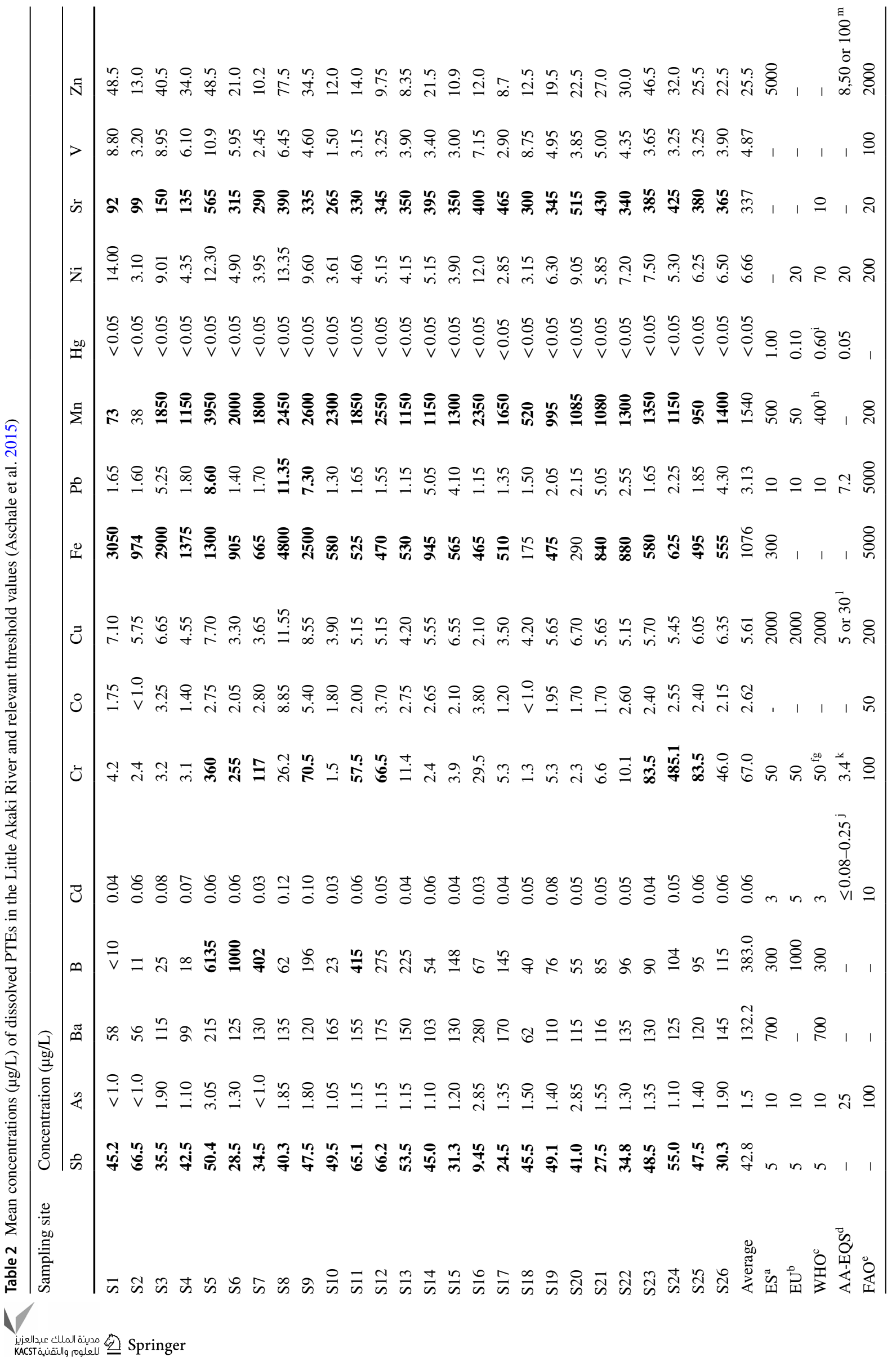


in this study was higher than the previously reported mean value of $1.82 \mu \mathrm{g} / \mathrm{L}$ by Melaku et al. (2004), the concentrations at all sites were less than the international guideline value for irrigation water of $50 \mu \mathrm{g} / \mathrm{L}$ (FAO, 1994). The values of $\mathrm{Zn}$ ranged from 8.35 to $77.5 \mu \mathrm{g} / \mathrm{L}$ with the mean value of $25.50 \mu \mathrm{g} / \mathrm{L}$ (Table 2). No health-based guideline values have been proposed for $\mathrm{Zn}$ in drinking water by the WHO but the Ethiopian Standard has a guide value of $5000 \mu \mathrm{g} / \mathrm{L}$. All the values obtained were below this limit and were also less than the international guideline value for irrigation water of $2000 \mu \mathrm{g} / \mathrm{L}$ (FOA 1994). However, all the concentrations of $\mathrm{Zn}$ were exceeded the $8 \mu \mathrm{g} / \mathrm{L}$ annual average threshold in SI 272 of 2009 for surface water with hardness value less than or equal to $10 \mathrm{mg} / \mathrm{L} \mathrm{CaCO}_{3}$. The levels of As in the analyzed water samples were in the range of 0.5 to $3.05 \mu \mathrm{g} / \mathrm{L}$ with the mean value of $1.46 \mu \mathrm{g} / \mathrm{L}$, all were within the acceptable limit specified as $10 \mu \mathrm{g} / \mathrm{L}$ for drinking water, $25 \mu \mathrm{g} / \mathrm{L}$ for surface water and $100 \mu \mathrm{g} / \mathrm{L}$ for irrigation water (Table 2).

The concentrations of $\mathrm{Ni}$ in the water samples were between 2.85 and $14 \mu \mathrm{g} / \mathrm{L}$ with the mean value of $6.66 \mu \mathrm{g} / \mathrm{L}$ (Table 2). All the concentrations were below the recommended limit of drinking water stipulated by the EU and WHO guidelines. The values were also much less than the international guideline value for irrigation water of $200 \mu \mathrm{g} / \mathrm{L}$ (FOA 1994). However, the mean concentration of $\mathrm{Ni}$ in this study was higher than the previously reported mean value of $4.63 \mu \mathrm{g} / \mathrm{L}$ by Melaku et al. (2004). The concentrations of $\mathrm{B}$ were in the range of $0.5-6135 \mu \mathrm{g} / \mathrm{L}$ with the mean value of $383.04 \mu \mathrm{g} / \mathrm{L}$. The recommended limit of B is specified as $300 \mu \mathrm{g} / \mathrm{L}$ by the WHO and Ethiopian standards for drinking water, whereas Sites S5, S6, S7 and S11 showed much higher concentrations than those guideline values. The concentrations of B in the water samples at Sites S5 and S6 also exceeded the standard value of $1000 \mu \mathrm{g} / \mathrm{L}$ set by the EU Directives (1998).

Fe values ranged from 175 to $4800 \mu \mathrm{g} / \mathrm{L}$ with the mean value of $1075.92 \mu \mathrm{g} / \mathrm{L}$. The concentrations in all the water samples (except at Sites S18 and S20) exceeded the recommended limit stipulated by the Ethiopian Standards $(300 \mu \mathrm{g} / \mathrm{L})$ for drinking water. The high Fe concentrations in this river water may be due to the Fe ore tailing from the metal workshops and discharge of iron-loaded industrial wastes. However, the river water meets the standards for irrigation as all values were below the threshold value of $5000 \mu \mathrm{g} / \mathrm{L}$ (FOA 1994). The concentrations of $\mathrm{Mn}$ in the analyzed water samples ranged from 38 to $3950 \mu \mathrm{g} / \mathrm{L}$ with the mean value of $1540 \mu \mathrm{g} / \mathrm{L}$. Mn contents in all the water samples except at Sites S1 and S2 exceeded the recommended limit stipulated by the WHO $(400 \mu \mathrm{g} / \mathrm{L}), \mathrm{EU}$ $(50 \mu \mathrm{g} / \mathrm{L})$ and Ethiopian standards $(500 \mu \mathrm{g} / \mathrm{L})$ for drinking water. The lower concentrations at Sites S1 $(73 \mu \mathrm{g} / \mathrm{L})$ and S2 $(38 \mu \mathrm{g} / \mathrm{L})$ are probably due to its location outside of the city

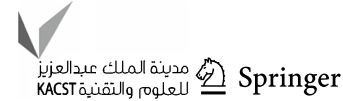




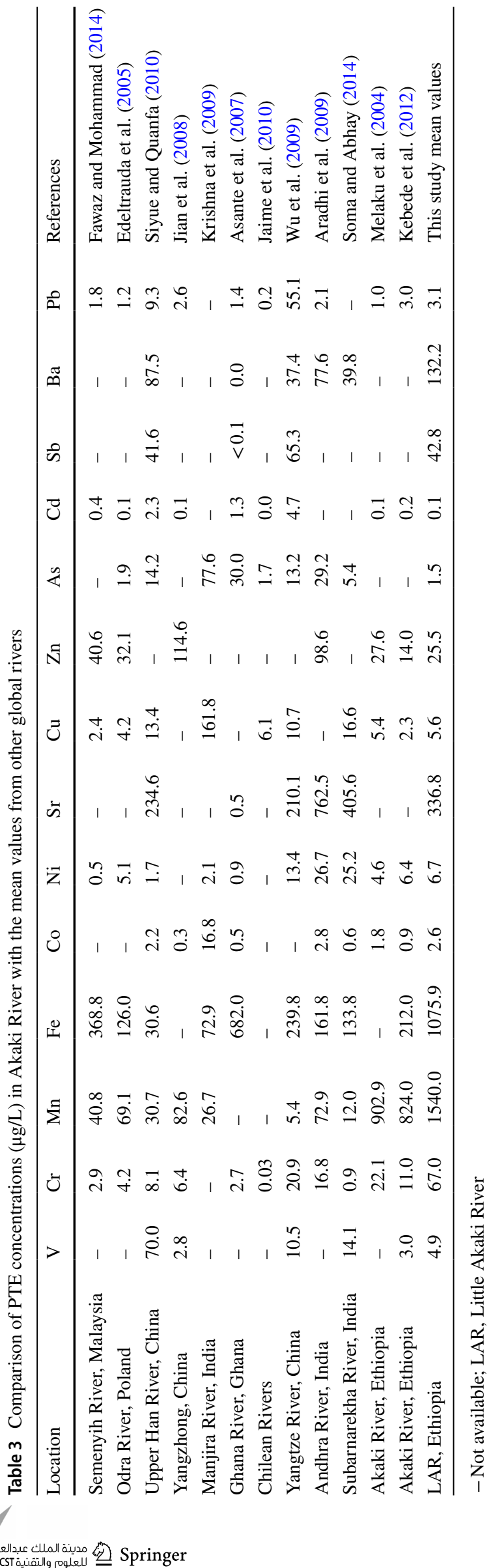

where it is free from anthropogenic discharges. The water samples from all sites (except at Sites S1 and S2) were unfit for irrigation purposes (FOA 1994). These elevated Mn concentrations in the Akaki River may be linked to the industrial activity, municipal, domestic and hospital wastes that discharge treated and untreated wastewater into the various drains feeding into the river (Table 2).

The concentrations of $\mathrm{V}$ in the analyzed water samples were in the range of $1.5-10.9 \mu \mathrm{g} / \mathrm{L}$ with the mean value of $4.87 \mu \mathrm{g} / \mathrm{L}$. These values were less than the international guideline value of $100 \mu \mathrm{g} / \mathrm{L}$ for irrigation water (FOA 1994). The concentrations of $\mathrm{Sb}$ ranged from 9.45 to $66.5 \mu \mathrm{g} / \mathrm{L}$ with the mean value of $42.80 \mu \mathrm{g} / \mathrm{L}$. The concentrations of $\mathrm{Sb}$ at all sampling sites exceeded the recommended limits of $5 \mu \mathrm{g} / \mathrm{L}$ as given by the WHO, EU and Ethiopian Standards for drinking water. No international guideline values are set for $\mathrm{Sb}$ in irrigation water. This is probably due to the assumption that the concentrations of $\mathrm{Sb}$ in irrigation water are generally negligible. The sources of $\mathrm{Sb}$ concentrations could be from industrial activities such as textile, glass and abandoned mine deposits along the river and its tributaries.

The concentrations of $\mathrm{Cd}$ in the study area varied from 0.03 to $0.12 \mu \mathrm{g} / \mathrm{L}$ with the mean value of $0.06 \mu \mathrm{g} / \mathrm{L}$, which was much less than the recommended limit for $\mathrm{Cd}$ in the drinking water of $3 \mu \mathrm{g} / \mathrm{L}$ set by the WHO and Ethiopian Standards. Furthermore, the values for $\mathrm{Cd}$ did also not exceed the international guideline value of $10 \mu \mathrm{g} / \mathrm{L}$ for irrigation water (FAO 1994), but the mean value was higher than the previously reported value of $0.048 \mu \mathrm{g} / \mathrm{L}$ by Melaku et al. (2004). The concentrations of $\mathrm{Sr}$ in the analyzed water samples ranged from 92 to $565 \mu \mathrm{g} / \mathrm{L}$ with the mean value of $336.75 \mu \mathrm{g} / \mathrm{L}$ (Table 2). The recommended limit is specified as $10 \mu \mathrm{g} / \mathrm{L}$ for drinking water by the WHO (2011) and $20 \mu \mathrm{g} / \mathrm{L}$ for irrigation water by the FAO (1994). The values obtained in all cases were much higher than these guideline values. The concentrations of $\mathrm{Sr}$ increased from upstream to downstream locations. Ba levels in analyzed water samples were in the range of $55.5-280 \mu \mathrm{g} / \mathrm{L}$ with the mean value of $132.17 \mu \mathrm{g} / \mathrm{L}$, which was lower than the WHO and Ethiopian Standards limit of $700 \mu \mathrm{g} / \mathrm{L}$.

The pollution level of PTEs (the mean values) in other rivers and streams from different regions of the world is shown in Table 3 to compare with the values obtained in the present study. The contaminations of $\mathrm{Mn}, \mathrm{Cr}, \mathrm{Fe}$ and $\mathrm{Ba}$ in the Little Akaki River sites were comparatively higher than the concentrations from these other studies (Table 3 ). The concentrations of $\mathrm{Co}, \mathrm{Pb}, \mathrm{Ni}, \mathrm{Zn}, \mathrm{Sr}, \mathrm{Cu}, \mathrm{Cd}, \mathrm{Sb}$ and $\mathrm{V}$ were in the ranges seen in the other contaminated rivers (Table 3). The level of As was in general lower than for other rivers. Overall, the degree of PTEs contamination in the Little Akaki River in the city of Addis Ababa was comparable to other PTEs polluted rivers worldwide. 
Table 4 Pearson's correlation coefficient between elements in the river water $(n=26)($ Aschale et al. 2015)

\begin{tabular}{|c|c|c|c|c|c|c|c|c|c|c|c|c|c|}
\hline Metal & $\mathrm{Sb}$ & As & $\mathrm{Ba}$ & B & $\mathrm{Cd}$ & $\mathrm{Cr}$ & Co & $\mathrm{Cu}$ & $\mathrm{Fe}$ & $\mathrm{Pb}$ & $\mathrm{Mn}$ & $\mathrm{Ni}$ & $\mathrm{Sr}$ \\
\hline As & -0.37 & & & & & & & & & & & & \\
\hline $\mathrm{Ba}$ & -0.34 & $0.57 * *$ & & & & & & & & & & & \\
\hline B & 0.10 & $0.47 *$ & 0.38 & & & & & & & & & & \\
\hline $\mathrm{Cd}$ & 0.16 & 0.18 & -0.22 & 0.05 & & & & & & & & & \\
\hline $\mathrm{Cr}$ & 0.15 & 0.14 & 0.22 & $0.56 * *$ & -0.04 & & & & & & & & \\
\hline Co & -0.04 & 0.28 & 0.27 & 0.03 & $0.64 * *$ & 0.08 & & & & & & & \\
\hline $\mathrm{Cu}$ & 0.23 & 0.21 & -0.25 & 0.17 & $0.72 * *$ & 0.02 & $0.63 * *$ & & & & & & \\
\hline $\mathrm{Fe}$ & -0.03 & 0.04 & -0.19 & 0.02 & $0.72 * *$ & -0.08 & $0.70 * *$ & $0.74 * *$ & & & & & \\
\hline $\mathrm{Pb}$ & -0.08 & $0.42 *$ & 0.07 & $0.40^{*}$ & $0.72 * *$ & 0.13 & $0.70 * *$ & $0.83 * *$ & $0.70 * *$ & & & & \\
\hline $\mathrm{Mn}$ & -0.10 & $0.55^{* *}$ & $0.74 * *$ & $0.62 * *$ & 0.24 & 0.37 & $0.52 * *$ & 0.16 & 0.18 & $0.50 * *$ & & & \\
\hline $\mathrm{Ni}$ & -0.21 & $0.54 * *$ & 0.24 & 0.31 & 0.35 & 0.09 & $0.60 * *$ & $0.58 * *$ & $0.66 * *$ & $0.55^{* *}$ & 0.33 & & \\
\hline $\mathrm{Sr}$ & -0.21 & $0.62 * *$ & $0.54 * *$ & $0.41 *$ & -0.10 & 0.36 & 0.16 & 0.08 & -0.30 & 0.28 & $0.47 *$ & 0.12 & \\
\hline V & -0.20 & $0.46^{*}$ & 0.02 & $0.50 * *$ & 0.29 & 0.14 & 0.15 & 0.25 & $0.45^{*}$ & 0.37 & 0.20 & $0.63 * *$ & -0.01 \\
\hline $\mathrm{Zn}$ & 0.01 & 0.24 & -0.13 & 0.24 & $0.60 * *$ & 0.20 & $0.60 * *$ & $0.77 * *$ & $0.81 * *$ & $0.70^{* *}$ & 0.21 & $0.74 * *$ & 0.01 \\
\hline
\end{tabular}

**Correlation is significant at the 0.01 level (2-tailed)

*Correlation is significant at the 0.05 level (2-tailed)

Table 5 Varimax rotated factor loadings and communalities for the river water dataset

\begin{tabular}{lrrrrl}
\hline Element & PC1 & PC2 & PC3 & PC4 & Communality \\
\hline $\mathrm{Cu}$ & $\mathbf{0 . 9 1}$ & -0.06 & 0.07 & 0.15 & 0.86 \\
$\mathrm{Fe}$ & $\mathbf{0 . 8 7}$ & -0.17 & 0.31 & -0.13 & 0.90 \\
$\mathrm{Cd}$ & $\mathbf{0 . 8 6}$ & -0.07 & 0.00 & 0.04 & 0.74 \\
$\mathrm{~Pb}$ & $\mathbf{0 . 8 4}$ & 0.29 & 0.18 & 0.13 & 0.84 \\
$\mathrm{Co}$ & $\mathbf{0 . 8 3}$ & 0.39 & -0.07 & -0.15 & 0.87 \\
$\mathrm{Zn}$ & $\mathbf{0 . 8 0}$ & -0.04 & 0.42 & 0.14 & 0.83 \\
$\mathrm{Ba}$ & -0.15 & $\mathbf{0 . 9 0}$ & 0.06 & -0.02 & 0.84 \\
$\mathrm{Sr}$ & 0.00 & $\mathbf{0 . 8 0}$ & -0.11 & 0.22 & 0.70 \\
$\mathrm{Mn}$ & 0.28 & $\mathbf{0 . 7 8}$ & 0.06 & 0.29 & 0.78 \\
$\mathrm{As}$ & 0.15 & $\mathbf{0 . 7 2}$ & 0.45 & 0.01 & 0.75 \\
$\mathrm{~V}$ & 0.22 & -0.01 & $\mathbf{0 . 9 1}$ & 0.15 & 0.90 \\
$\mathrm{Ni}$ & 0.57 & 0.25 & $\mathbf{0 . 6 3}$ & -0.06 & 0.79 \\
$\mathrm{Cr}$ & -0.01 & 0.27 & 0.08 & $\mathbf{0 . 7 6}$ & 0.66 \\
$\mathrm{~B}$ & 0.04 & 0.42 & 0.42 & $\mathbf{0 . 7 2}$ & 0.87 \\
$\mathrm{Sb}$ & 0.15 & -0.42 & -0.41 & $\mathbf{0 . 6 2}$ & 0.75 \\
Total eigenvalues & 5.82 & 3.31 & 1.55 & 1.39 & - \\
Variance (\%) & 38.77 & 22.07 & 10.33 & 9.26 & - \\
\hline
\end{tabular}

Bold data are the main contribution elements to the component

\section{Correlation analysis}

To explore possible common sources of the PTEs in river water, Pearson correlation coefficients were calculated and are summarized in Table 4. A correlation coefficient (r) value of more than 0.7 indicates a high level of significance, between 0.5 and 0.7 is moderately significant and less than
0.5 is insignificant. If the Pearson correlation coefficient between PTEs is positive, they may have a common source, mutual dependence and similar behavior during transportation (Saeedi et al. 2012; Fei et al. 2013). The results showed strong positive correlations between $\mathrm{Cu}-\mathrm{Pb}(r=0.83)$, $\mathrm{Cu}-\mathrm{Zn}(r=0.77), \mathrm{Zn}-\mathrm{Fe}(r=0.81), \mathrm{Cu}-\mathrm{Cd}(r=0.72)$, $\mathrm{Cd}-\mathrm{Fe}(\mathrm{r}=0.72), \mathrm{Cd}-\mathrm{Pb}(r=0.72), \mathrm{Pb}-\mathrm{Zn}(r=70)$, $\mathrm{Cu}-\mathrm{Fe}(r=0.74)$, Co-Fe $(r=0.70)$, Co-Pb $(r=0.70)$, $\mathrm{Ni}-\mathrm{Zn}(r=0.74)$ and $\mathrm{Fe}-\mathrm{Pb}(r=0.70)$ at significant level $p<0.01$, forming a group of $\mathrm{Cu}-\mathrm{Pb}-\mathrm{Zn}-\mathrm{Fe}-\mathrm{Cd}-\mathrm{Co}-\mathrm{Ni}$ (Table 4). This suggests that these PTEs originated from common contamination sources as oxides and hydroxides (Mrazovac and Mirjana 2011). Also significant but relatively moderate correlations $(p<0.01)$ were found between Cd-Co $(r=0.64), \mathrm{Co}-\mathrm{Zn}(r=0.60), \mathrm{Cd}-\mathrm{Zn}(r=0.60)$, $\mathrm{Co}-\mathrm{Ni}(r=0.60)$, Co-Cu $(r=0.63)$, Fe-Ni $(r=0.66)$, $\mathrm{Pb}-\mathrm{Ni}(r=0.55), \mathrm{Pb}-\mathrm{Mn}(r=0.50), \mathrm{Ni}-\mathrm{V}(r=0.63)$, B-Mn $(r=0.62)$, AsMn $(r=0.55)$, As-Ni $(r=0.54)$, $\mathrm{Cu}-\mathrm{Ni}(r=0.58), \mathrm{As}-\mathrm{S} r(r=0.62), \mathrm{Ba}-\mathrm{S} r(r=0.54), \mathrm{As}-\mathrm{Ba}$ $(r=0.57)$, Co-Ni $(r=0.60)$ and $\mathrm{Co}-\mathrm{Mn}(r=0.52)$, suggesting that the source of these PTEs was to some extent linked. Ba was significantly positively correlated with $\mathrm{Mn}(r=0.74)$ at $p<0.01$. A considerable number of significant correlations $(p<0.01)$ were also observed between As-Ba $(r=0.57)$, As-Mn $(r=0.55)$, As-Ni $(r=0.54)$, $\mathrm{B}-\mathrm{Cr}(r=0.56)$ and $\mathrm{B}-\mathrm{V}(r=0.50)$. Also significant but relatively weak correlations $(p<0.05)$ were found between $\mathrm{B}-\mathrm{Sr}(r=0.41), \mathrm{As}-\mathrm{B}(r=0.47), \mathrm{As}-\mathrm{V}(r=0.46), \mathrm{As}-\mathrm{Pb}$ $(r=0.42), \mathrm{Fe}-\mathrm{V}(r=0.45)$ and $\mathrm{B}-\mathrm{Pb}(r=0.40)$ (Table 4). These findings may be related to the adsorption of PTEs by oxides or hydroxides. 
Fig. 2 Biplot of scores and loadings matrices for the first two PCs of river water samples
Fig. 3 Dendrogram from the cluster analysis of 15 elements in 26 sampling sites on the Akaki River and its main tributaries
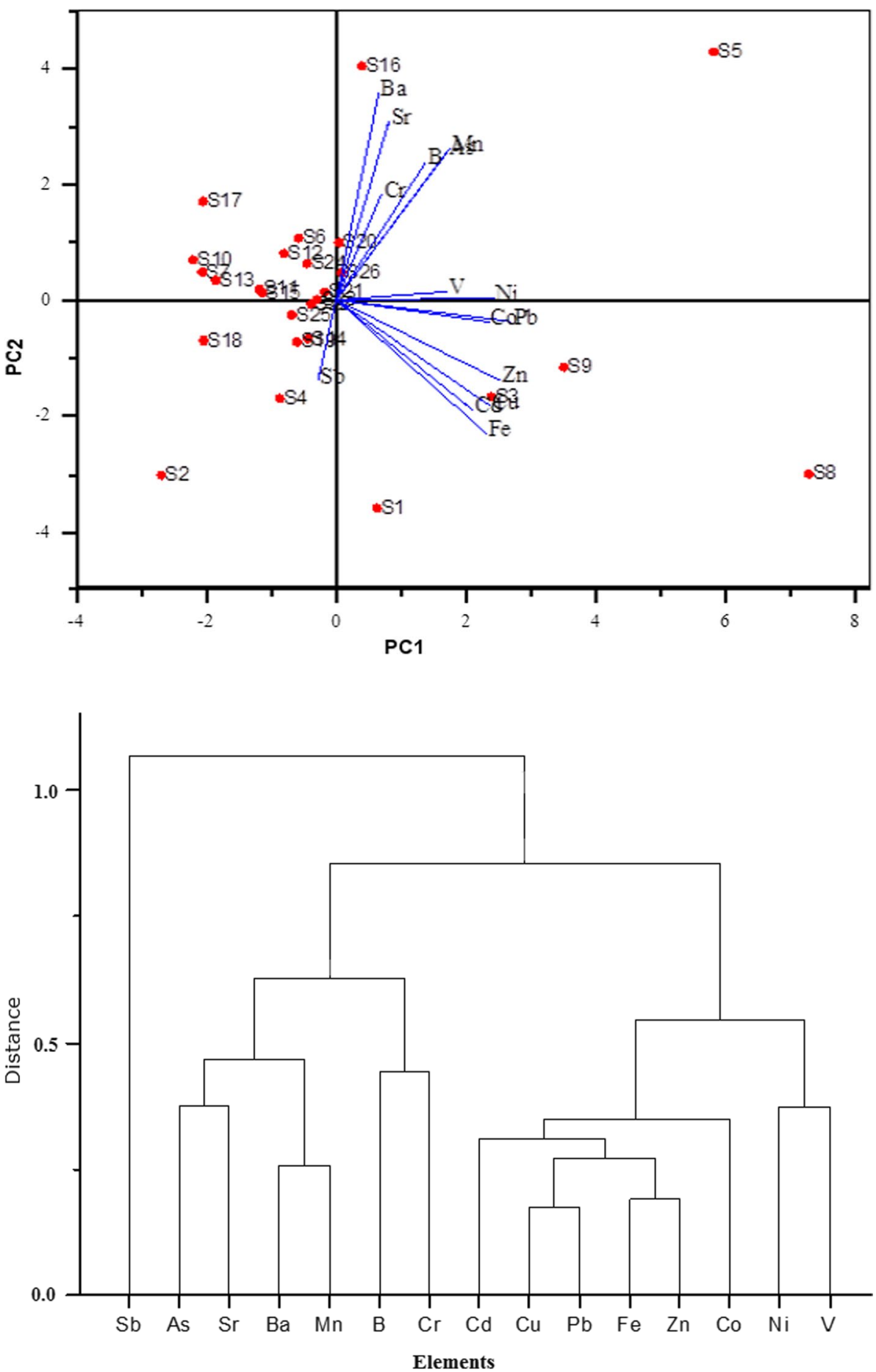

\section{Principal component analysis (PCA)}

In this study, the test value of KMO (0.69) demonstrated that PTE concentration datasets from the river and its main tributaries were suitable for PC analysis. Similarly, the sphericity tests of Bartlett's showed that whether the matrix of correlation is an identity that could signify that variables are not associated. The significance level $(\sigma=0.00, d f=105)$ which was less than 0.05 indicated that there were significant relations between variables. The 15 variables (PTE concentrations) from 26 sampling locations were used as the multivariate dataset. The resulting varimax of the rotated principal component loading is summarized in Table 5 and a biplot of the principal component analysis loading is presented in Fig. 2. The variance of communalities with high values $(0.66-0.90)$ showed the extracted factors fit well with 
Fig. 4 Cluster analysis of 26 sampling sites based on the element loading in river water

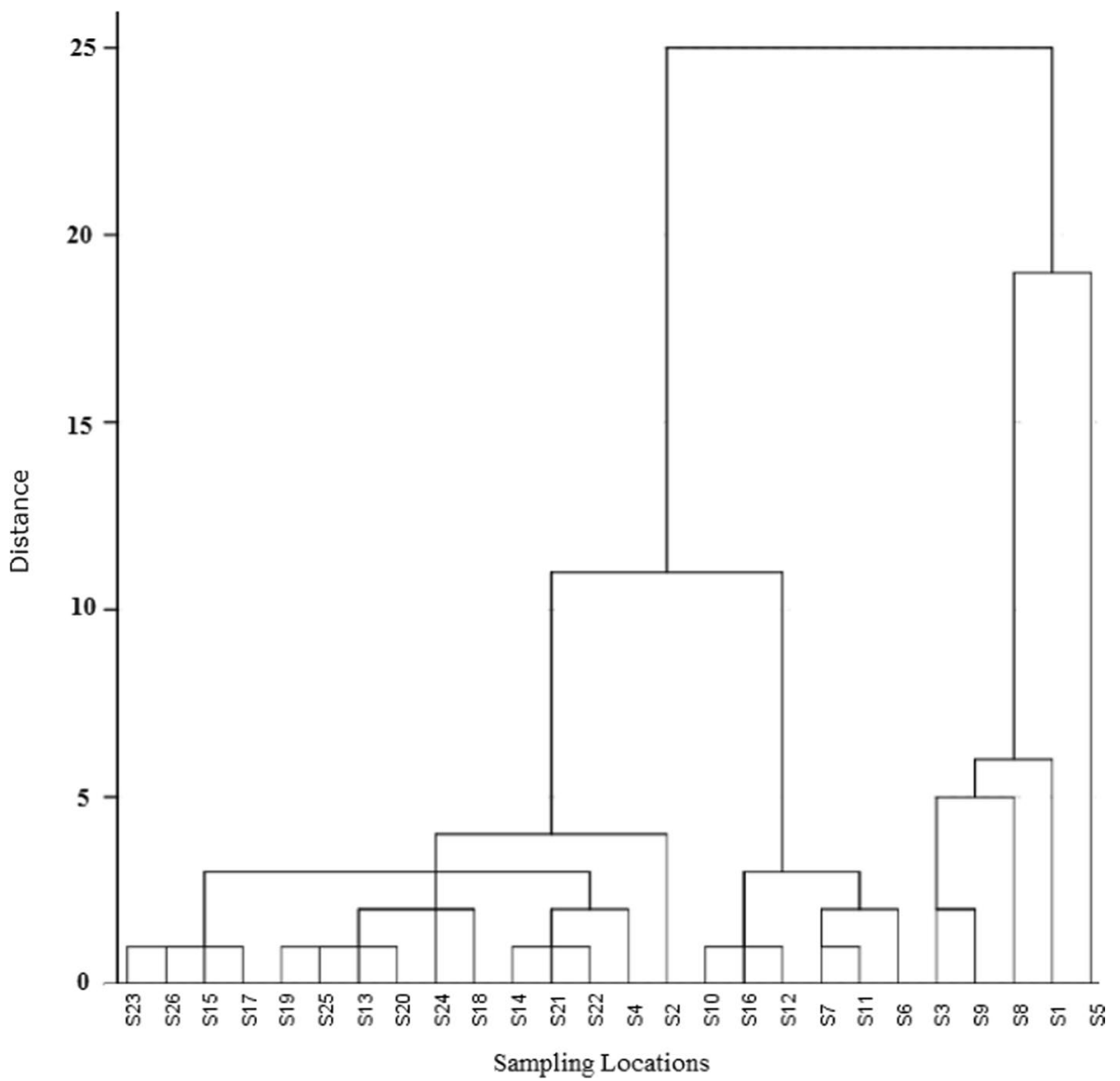

the factor solution. The present study showed that the first four PCs represented about $80.43 \%$ of the total variance in the datasets from eigenvalues $>1$. The first PC1 with $38.77 \%$ of the total variance had a strong positive loading of $\mathrm{Fe}, \mathrm{Cd}$, $\mathrm{Pb}, \mathrm{Cu}, \mathrm{Co}$ and $\mathrm{Zn}$ (Table 5). These relationships strongly propose that these variables had a strong association due to discharge of clinical, industrial, municipal and domestic wastes. The second PC2 accounted for $22.07 \%$ of the total variance, with a positive loading of $\mathrm{Ba}, \mathrm{Sr}, \mathrm{Mn}$ and $\mathrm{As}$. The third PC3 had a strong positive loading on $\mathrm{V}$ and $\mathrm{Ni}$ and represented $10.33 \%$ of the total variance. The fourth component (PC4) was associated with the $9.26 \%$ of total variance weighted on $\mathrm{Cr}, \mathrm{Ba}$ and $\mathrm{Sb}$.

The results of the PCA were well matched with the results of the Pearson correlation analysis. The strong and moderate loading on PTEs suggests pollution associated with anthropogenic activities such as the discharge of clinical, industrial, municipal and domestic wastes to the streams and rivers, and also from farming activities taking place along the course of the river. In the study areas, some of the industrial activities that are likely sources of the PTEs are the production of alloys, pigments, electrical wiring, batteries and dye production, glass and plastics, cooking utensils, electroplating, tanneries, insecticides and fungicides.

\section{Cluster analysis (CA)}

$\mathrm{CA}$ was applied to the data based on 15 variables $(\mathrm{Sb}, \mathrm{Zn}$, $\mathrm{Cd}, \mathrm{Sr}, \mathrm{Cu}, \mathrm{Pb}, \mathrm{Fe}, \mathrm{V}, \mathrm{Ni}, \mathrm{Co}, \mathrm{Mn}, \mathrm{Cr}, \mathrm{B}, \mathrm{As}$ and $\mathrm{Ba}$ ) at 26 sampling locations or sites. The corresponding cluster analysis dendrogram derived is shown in Fig. 3. Five clusters were identified as Cluster $1(\mathrm{Sb})$, Cluster $2(\mathrm{Sr}, \mathrm{Ba}$, As and $\mathrm{Mn}$ ), Cluster 3 (B and $\mathrm{Cr}$ ), Cluster $4(\mathrm{Cu}, \mathrm{Zn}, \mathrm{Fe}, \mathrm{Cd}$, $\mathrm{Pb}$ and $\mathrm{Co}$ ) and Cluster $5(\mathrm{Ni}$ and $\mathrm{V})$ at a distance of 0.5 . Cluster 2 and 4 again alienated into sub-clusters due to the main differences among sampling locations. Cluster 2 and 3,4 and 5 join together at a relatively lower level implying a likely a common source of pollution while the long-distance Cluster 1 showed that this grouping might have a different or separate source. From the result of the analysis, it can be summarized that there was a strong co-correlation among $\mathrm{Cd}, \mathrm{Cu}, \mathrm{Pb}, \mathrm{Fe}, \mathrm{Zn}$ and Co pair showed a good agreement with $\mathrm{PC} 1(\mathrm{Cu}, \mathrm{Fe}, \mathrm{Cd}, \mathrm{Pb}, \mathrm{Co}$ and $\mathrm{Zn}), \mathrm{As}, \mathrm{Sr}, \mathrm{Ba}$ and $\mathrm{Mn}$ pair which was in good agreement with PC2 ( $\mathrm{Ba}, \mathrm{Sr}, \mathrm{Mn}$ and As), $\mathrm{V}$ and Ni pair with PC3 (V and Ni), B and Cr pair had a good agreement with PC4 ( $\mathrm{Cr}$ and $\mathrm{B})$, verifying that the variables had a strong interrelationship. PTEs that fit into the same groups or clusters were probable to have come from a common source of pollution (Faisal et al. 2014). 
Similarly, cluster analysis computed by sampling locations was undertaken and the dendrogram attained illustrates the spatially geochemical grouping of 26 locations based on all fifteen PTE concentrations in water samples (Fig. 4). Cluster 1 (S2, S4, S13, S14, S15, S17, S18, S19, S20, S21, S22, S23, S24, S25 and S26), Cluster 2 (S6, S7, S10, S11, S12 and S16), Cluster 3 (S1, S3, S8 and S9) and Cluster 4 (S5) were formed at a distance of 10 (Fig. 4). Cluster 1, 2 and 3 were again alienated into sub-clusters due to the main differences among sampling locations. Sampling sites belonging to the same groups or clusters were likely to have similar loads of toxic and PTEs. Cluster 4 represents sampling site S5 on the Little Akaki River after mixing with Addis Ababa Tannery and the glass factory wastes, which was relatively high in PTE concentrations.

\section{Conclusions}

The findings of the river and its main tributaries water quality assessment by multivariate statistical methods have obviously provided the basis for describing and detecting spatial variation and identifying prospective pollution sources. The pollution levels of the river were lowest in sites upstream of the city boundary where no factories are located, highest in Akaki-kalit industrial areas in the southern parts of Addis Ababa while concentrations declined with distance farther downstream. Although some of the contaminants were below the maximum acceptable values suggested by the international guideline values for drinking water, some PTEs were found to exceed the recommended levels at some sampling locations. The values of most PTEs recorded in the study were relatively higher than previously reported. These could be due to recent rapid urbanization and industrialization, continuing poor waste management system, and direct discharge of municipal and domestic wastes, industrial effluents, wastewater from health facilities, petrol stations and garages into the river and its tributaries. Besides, the catchment area of the Akaki River is well cultivated where the uses of organometallic chemicals are common. Washing of automobiles near the river/streams could also increase PTE concentrations such as $\mathrm{Pb}$ in the river. The major streams or tributaries of the Little Akaki River also added to the contamination load of the river, as they are used as a receptacle of all kinds of point and non-point source wastes released in the city. These findings should help highlight and focus water quality management on key PTEs of concern and prioritize efforts to mitigate their release into surface waters in the city.

Acknowledgements This project was financially supported by the University of Addis Ababa-Connecticut University, USA, and the Irish Environmental Protection Agency (IEPA), Ireland. Access to the laboratory facilities of EPA, University of College Dublin (UCD) is acknowledged.

Funding This project was financially supported by the University of Addis Ababa-Connecticut University, USA, and the Irish Environmental Protection Agency (IEPA), Ireland.

\section{Declarations}

Conflict of interest The authors declare that they have no conflicts of interest.

Open Access This article is licensed under a Creative Commons Attribution 4.0 International License, which permits use, sharing, adaptation, distribution and reproduction in any medium or format, as long as you give appropriate credit to the original author(s) and the source, provide a link to the Creative Commons licence, and indicate if changes were made. The images or other third party material in this article are included in the article's Creative Commons licence, unless indicated otherwise in a credit line to the material. If material is not included in the article's Creative Commons licence and your intended use is not permitted by statutory regulation or exceeds the permitted use, you will need to obtain permission directly from the copyright holder. To view a copy of this licence, visit http://creativecommons.org/licenses/by/4.0/.

\section{References}

AAEPA, Addis Ababa Environmental Protection Agency (2008) Trends of industrial water pollution in Addis Ababa, the case of tanneries, textiles, paint, food and beverages factories

Akan J, Kolo B, Yikala B, Ogugbuaja V (2013) Determination of some heavy metals in vegetable samples from Biu Local Government Area, Borno State North Eastern Nigeria. Int J Environ Monit Assess 11:40-46

Aradhi K, Satyanarayanan M, Pradip K (2009) Assessment of heavy metal pollution in water using multivariate statistical techniques in an industrial area: a case study from Patancheru, Medak District, Andhra Pradesh, India. J Hazard Mater 167: 366-373

Asante K, Agusa T, Subramanian A, Ansa A, Biney C, Tanabe S (2007) Contamination status of arsenic and other trace elements in drinking water and residents from Tarkwa: a historic mining township in Ghana. Chemosphere 66: 1513-1522

Aschale M, Sileshi Y, Quinn M, Hailu D (2016) Evaluation of potentially toxic element pollution in the benthic sediments of the water bodies of the city of Addis Ababa, Ethiopia. J Environ Chem Eng 4:4173-4183

Aschale M, Sileshi Y, Kelly-Quinn M and Hailu D (2015) Potentially toxic trace element contamination of the Little Akaki River of Addis Ababa. J Nat Sci Res 5(1): 1-13

Ayers R, Westcot D (1994) Water quality for agriculture: FAO irrigation and drainage. Paper 29 Rev. 1, FAO, Italy

Botikin D and Keller E (1995). Environmental Science. Earth as a living planet. John Wiley and Son Inc. New York, USA. $7^{\text {th }}$ Edition. pp 410-476.

Daniel F, Fisseha I, Olsson M (2007) Total contents and sequential extraction of heavy metals in soils irrigated with wastewater, Akaki, Ethiopia. Environ Manag 39: 178-193

ES, Ethiopian Standard, (2001) National drinking water guidelines: recommendations (draft report). Ministry of Water Resources, Addis Ababa

EU, European Union Directive 1998/83/EC (1998) Council directive 98/83/EC of 3 Nov. (1998) on the quality of water intended for human consumption. Off J Eur Commun 330(41): 32-54 
Edeltrauda H, Ewa A, Aleksander K (2005) Distribution of trace metals in the Odra River system: water-suspended matter-sediments. Limnologica 35: 185-198

Edem C, Akpan S, Dosunmu M (2008) A Comparative assessment of heavy metals and hydrocarbon accumulation in sphyrena afra, orechromis niloticus and elops lacerta from Anantigha Beach market in Calabar-Nigeria. Afr J Environ Pollut Health 6: 61-64.

Faisal B, Majumder R, Uddin M, Halim M (2014) Studies on heavy metals in industrial effluent, river and groundwater of Savar Industrial area, Bangladesh. Int J Geom Geosci 5(1): 182-191

Fawaz A, Mohammad S (2014) Heavy metals and water quality assessment using multivariate statistical techniques and water quality index of the Semenyih River, Peninsular Malaysia. Iron J Energy Environ 5(2): 132-145

Fei L, Jinhui H, Guangming Z, Xingzhong Y, Xiaojiao T, Bing B (2013) Spatial risk assessment and sources identification of heavy metals in surface sediments from the Donating Lake, Middle China. J Geochem Explor 132: 75-83

Gebre G and Rooijen V (2009). Urban water pollution and irrigated vegetable farming in Addis Abeba. Paper presented for $34^{\text {th }}$ WEDC International Conference, Addis Abeba, Ethiopia. Refereed Paper: 166.

Gupta C, Rai R, Pandey S, Sharma B (2009) Analysis of some heavy metals in the riverine water, sediments and fish from river Ganges at Allahabad. Environ Monit Assess 157:449-458

Han G, Liu C (2004) Water geochemistry controlled by carbonate dissolution: a study of the river waters draining karst-dominated terrain, Guizhou province, China. Chem Geol 204: 1-21

Itanna F (1998) Metal concentrations of some vegetables irrigated with industrial liquid waste at Akaki, Ethiopia. Ethiop J Sci 21(1): 133-144

Jaime P, Pablo M, Jose A, Alejandra M (2010) Heavy metals in northern Chilean Rivers: spatial variation and temporal trends. J Hazard Mater 181: 747-754

Jian Z, Dongsheng M, Jiayong P, Wenming N, Kai W (2008) Application of multivariate statistical approach to identify heavy metal sources in sediment and waters: a case study in Yangzhong, China. Environ Geol 54: 373-380

Kar D, Sur P, Mandal S, Saha T and Kole R (2008). Assessment of heavy metal pollution in surface water. Int J Environ Sci Technol 5(1): 119-124

Kebede N, Abayneh A, Bhagwan S, Mesfin R, RobertIan M (2012) Potentially toxic elements in some fresh water bodies in Ethiopia. Toxicol Environ Chem 94(10): 1980-1994

Krishna A, Satyanarayanan M, Govil P (2009) Assessment of heavy metal pollution in water using multivariate statistical techniques in an industrial area: a case study from Patancheru, Medak District, Andhra Pradesh, India. J Hazard Mater 167: 366-373

Lee C, Li X, Zhang G, Li J, Ding A, Wang T (2007) Heavy metals and $\mathrm{Pb}$ isotopic composition of aerosols in urban and suburban areas of Hong Kong and Guangzhou, South China Evidence of the longrange transport of air contaminants. Environ Pollut 41(2): 432-447

Lohani M, Singh S, Rupainwa D, Dhar D (2008). Seasonal variations of heavy metal contamination in river Gomti of Lucknow city region. Environ Monit Assess 147(1): 253-263

Marta S, Raul S (2008) Accumulation and movement of four potentially toxic elements in soils throughout five Years, during and after biosolid application. Am J Environ Sci 4(6): 576-582

Melaku S, Wondimu T, Dams R, Moens L (2004) Simultaneous determination of trace elements in Tinishu Akaki River water sample, Ethiopia, by ICP-MS. Can J Anal Sci Spectrosc 49(6): 374-384
Melaku S, Wondimu T, Dams R, Moens L (2005) Multi-element analysis of Tinishu Akaki River sediment, Ethiopia, by ICP-MS after microwave assisted digestion. Can J Anal Sci Spectrosc 50(1): $31-40$

Mrazovac S, Mirjana V (2011) Correlation of main physicochemical parameters of some groundwater in northern Serbia. J Geochem Explor 108: 176-182

Munk L, Faure G (2004) Effects of pH fluctuations on potentially toxic metals in the water and sediment of the Dillon Reservoir, Summit County, Colorado. Appl Geochem 19: 1065-1074

Nair I, Singh K, Arumugam M, Gangadhar K, Clarson D (2010) Trace metal quality of Meenachil River at Kottayam, Kerala by principal component analysis. World Appl Sci J 9(10): 1100-1107

Pandey G, Madhuri S (2014) Heavy metals causing toxicity in animals and fishes. Res J Anim Vet Fish Sci 2: 17-23

S.I. No. 272/2009-European communities environmental objectives (surface waters) regulations 2009. Environmental Quality Standards (EQS)

Saeedi M, Li L, Salmanzadeh M (2012) Heavy metals and polycyclic aromatic hydrocarbons: pollution and ecological risk assessment in street dust of Tehran. J Hazard Mater 227: 9-17

Sekabira K, Oryem O, Basamba T, Mutumba G, Kudidi E (2010) Assessment of heavy metal pollution in the urban stream sediments and its tributaries. Int J Environ Sci Technol 7:435-446

Shao W, Wen L (2004) Heavy metal phytoremediation by water hyacinth at constructed wetlands in Taiwan. J Aquat Plant Manag 42: $1117-1152$

Siyue L, Quanfa Z (2010) Spatial characterization of dissolved trace elements and heavy metals in the upper Han River (China) using multivariate statistical techniques. J Hazard Mater 176: 579-588

Soma G, Abhay K (2014) Risk assessment, statistical source identification and seasonal fluctuation of dissolved metals in the Subarnarekha River, India. J Hazard Mater 265: 305-314

Tamiru A, Dagnachew L, Tenalem A, Yirga T, Solomon W, Nuri M (2005) Hydrogeology, water quality and the degree of ground water vulnerability to pollution in Addis Ababa. Ethiopia, UNEP and UNESCO, Addis Ababa

Tamiru A (2001) The impact of uncontrolled waste disposal on surface water quality in Addis Ababa, Ethiopia. Ethiop J Sci 24(1): 93-104

WHO (2011) Guidelines for Drinking Water Quality, 4th edn. Geneva, Switzerland

Weldegebriel Y, Chandravanshi B, Wondimu T (2012) Concentration levels of metals in vegetables grown in soils irrigated with river water in Addis Ababa, Ethiopia. Ecotoxicol Environ Saf 77(1): 57-63

Wu B, Zhao D, Jia H, Zhang Y, Zhang X, Cheng S (2009) Preliminary risk assessment of trace metal pollution in surface water from Yangtze River in Nanjing Section, China. Bull Environ Contaminat Toxicol 82: 405-409

Zarazua G, Avila P, Tejeda S, Barcelo I, Martinez T (2006) Analysis of total and dissolved heavy metals in surface water of a Mexican polluted river by total reflection X-ray fluorescence spectrometry. Spectrochim Acta Part B Atom Spectrosc 61: 1180-1184

Publisher's Note Springer Nature remains neutral with regard to jurisdictional claims in published maps and institutional affiliations. 